Agus Setio Widodo,

Soesi Idayanti,

Dyah Irma Permanasari,

Agus Sahri,

dosenmuda@yahoo.co.id

Fakultas Ilmu Sosial dan Ilmu Politik

Universitas Pancasakti Tegal

\section{Kebijakan Relokasi Pedagang Kaki Lima (PKL) di Kawasan Kota Tegal}

\begin{abstract}
ABSTRAK
Akselerasi pembangunan daerah perkotaan akan berakibat pada peningkatan kebutuhan akan sandang, pangan, papan, beserta prasarana dan sarana penunjangnya yang selanjutnya berdampak pada peningkatan kebutuhan investasi. Disamping itu investasi diperlukan umtuk mempertahankan tingkat pertumbuhan ekonomi yang tinggi dan agar tetap dapat bersaing dalam pasar global.

Sebagai bagian integral dari pembangunan nasional, tujuan pembangunan Kota Tegal tidak terlepas dari tujuan pembangunan nasional itu sendiri yang ingin mewujudkan suatu masyarakat yang adil dan makmur, merata baik spirituil maupun materiil berdasarkan Pancasila dan Undang-Undang Dasar 1945 dalam wadah Negara Kesatuan Republik Indonesia. Untuk itu upaya pelaksanaan pembangunan daerah senantiasa didasarkan pada otonomi yang semakin nyata, dinamis, serasi dan bertanggung jawab dalam rangka untuk lebih meningkatkan aspek pemerataan pembangunan dan hasil-hasilnya.

Kebijakan relokasi pedagang kaki lima (PKL) di sekitar alun-alun dan Jl. Pancasila kota Tegal merupakan upaya pemerintah kota Tegal untuk mengatur keberadaan PKL yang selama ini dianggap menggangu ketertiban umum.
\end{abstract}

Kata kunci: kebijakan, relokasi, PKL

\section{A. Pendahuluan}

Indonesia sebagai negara yang sedang berkembang, selalu melakukan pem-bangunan di segala bidang termasuk bidang fisik untuk peningkatan sarana dan prasarana yang ada pada saat ini. Bidang-bidang lain yang masih sangat memerlukan peningkatan diantaranya adalah transpotasi dan peningkatan pembangunan ekonomi. Semua kegiatan pembangunan tersebut merupakan aktivitas manusia yang di-tujukan untuk peningkatan kesejahtera-an manusia.
Pembangunan Nasional yang berlangsung saat ini memasuki era baru yaitu demokrasi, otonomi daerah serta globalisasi. Hal tersebut memberi konsekuensi terhadap perkembangan wilayah perkotaan yang ada pada tiaptiap daerah terutama pada ruang perkotaan yang tercipta sangat beragam. Pengembangan suatu wilayah perkotaan mengindikasikan bahwa kawasan perkotaan merupakan konsentrasi pemukiman dengan segala kebutuhan penunjangnya bagi pembangunan sumber daya manusia dan kualitas kehidupan. Penataan ruang 
dengan penerapannya yang berupa penetapan kebijakan umum, penyusunan dan pelaksanaan program penbangunan sarana dan kinerja element-element kota merupakan kegiatan pembangunan kota yang kompleks dan komprehensif. Proses pembangunan wilayah perkotaan yang sangat beragam ini memerlukan kemampuan penanganan yang sangat kontekstual. Kebijakan desentralisasi seperti tertuang dalam Undang-undang Nomor 8 tahun 2009 Tentang Pemerintahan Daerah, tidak dapat direalisasikan apabila kemampuan sumber daya manusia tidak disiapkan. Sebagaimana diamanatkan dalam Garis Garis Besar Haluan Negara (GBHN), pendayagunaan sumber daya alam sebagaimana pokok-pokok kemakmuran rakyat harus dilakukan secara terencana, rasional, optimal, bertanggungjawab dan sesuai dengan kemampuan daya dukung-nya dengan mengutamakan sebesar-besarnya kemakmuran rakyat serta memperhatikan kelestarian dan keseimbangan lingkungan hidup bagi pembangunan yang berkelanjutan.

Akselerasi pembangunan daerah perkotaan akan berakibat pada peningkatan kebutuhan akan sandang, pangan, papan, beserta prasarana dan sarana penunjangnya yang selanjutnya berdampak pada peningkatan kebutuhan investasi. Disamping itu investasi diperlukan umtuk mempertahankan tingkat pertumbuhan ekonomi yang tinggi dan agar tetap dapat bersaing dalam pasar global.

Sebagai bagian integral dari pembangunan nasional, tujuan pem- bangunan Kota Tegal tidak terlepas dari tujuan pembangunan nasional itu sendiri yang ingin mewujudkan suatu masyarakat yang adil dan makmur, merata baik spirituil maupun materiil berdasarkan Pancasila dan UndangUndang Dasar 1945 dalam wadah Negara Kesatuan Republik Indonesia. Untuk itu upaya pelaksanaan pembangunan daerah senantiasa didasarkan pada otonomi yang semakin nyata, dinamis, serasi dan bertanggung jawab dalam rangka untuk lebih meningkatkan aspek pemerataan pembangunan dan hasil-hasilnya.

Dalam kerangka desentralisasi pemerintahan yang sekarang perlu diupayakan pembangunan prasarana dan sarana perkotaan secara terus menerus, guna memelihara prasarana dan sarana yang telah dibangun dan mengejar ketinggalan maupun kekurangan, serta memenuhi kebutuhan yang meningkat karena pertambahan penduduk dan kegiatan ekonomi perkotaan.

Kota Tegal adalah salah satu kota yang tanggap dalam memacu peningkatan kegiatan pembangunan kota. Kalau selama ini banyak kalangan yang mengenal Kota Tegal hanya karena stereotip yang melekat dari dialek masyarakatnya, Tegal juga diidentikkan masyarakatnya yang banyak mengadu nasib di kota-kota besar dengan membuka warung makan "Warteg". Hal ini memang tidak salah, tetapi sebenarnya potensi kota Tegal tersebut sangat besar.

Krisis moneter yang mulai terjadi sejak pertengahan tahun 1997 yang lalu 
pada masyarakat Kota Tegal dampaknya terhadap berbagai aspek kehidupan di dalam masyarakat masih terasa hingga sekarang, seperti dampak sosial, dampak politik, dampak terhadap hukum, dampak budaya serta yang sangat terasa adalah dampak ekonomi dan lainnya. Fenomena bangsa yang kian menjadikan resah bagi masyarakat tersebut berkembang menjadi krisis multidimensi. Beberapa indikasi yang bisa dilihat dari adanya krisis ini dan dampak lanjutan yang dirasakan adalah tidak adanya penyerapan tenaga kerja bahkan menyebabkan terjadinya Pemutusan Hubungan Kerja ( PHK ), hal ini tentu saja akan berakibat pada rendahnya tingkat pendapatan masyarakat di satu sisi.

Pembangunan kota Tegal dapat dijabarkan sebagai suatu upaya sadar dari manusia untuk meningkatkan kesejahteraan umat manusia, dimana manusia tersebut selalu bertambah jumlahnya, dan juga selalu bertambah keinginannya, jadi pembangunan secara umum sangat diharapkan nantinya akan dapat meningkatkan kesejahteraan umat manusia yang semakin bertambah jumlah dan keinginannya. Fenomena ini disatu pihak sangat menggembirakan karena merupakan peluang untuk terus meningkatkan kegiatannya dibidang ekonomi, namun disisi lain tentunya juga harus tanggap terhadap dampak yang akan ditimbulkannya.

Proses perkembangan pembangunan Kota Tegal didukung berbagai infrastruktur yang ada. Permasalahan utama dalam mencapai tujuan-tujuan tersebut terletak pada pola pemikiran kebijakan pemerintah kota dalam pe- laksanaan program yang telah dirancang. Sangat diperlukan adanya pergeseran dari pendekatan pembangunan secara fisik semata, mejadi lebih pada pe-nekanan perspektif sosioekonomi dengan program-program berbasiskan masyarakat. Masyarakat lebih diberdayakan untuk mengembangkan inisiatif dalam pendidikan, kesehatan, rekreasi dan hiburan serta fasilitas public lainnya. Hal ini akan menjadi bagian dari keseluruhan usaha untuk menggunakan setiap potensi sumber daya, menuju pada penciptaan daya tarik ekonomi, pelayanan masyarakat serta untuk menarik minat investor berdasarkan daya dukung lingkungan yang ada.

Tegal sebagai kota yang sedang giat-giatnya melaksanakan pembangunan sangat menekankan pada dimensi pada kebijakan pemerintah terhadap perencanaan tata kota, peningkatan kesempatan kerja dan pendapatan masyarakat serta fasilitas publik.yang diharapkan dapat dimanfaatkan secara optimal, dengan memperhatikan Peraturan Daerah (Perda) Nomor 05 Tahun 2002 yang merupakan perubahan Perda Nomor 11 Tahun 2001 Tentang Restribusi Pemakaian Kekayaan Daerah maka lahan yang selama ini belum digunakan diharapkan dapat dimanfaatkan lebih optimal. Pembangunan yang selama ini dilaksanakan di kota Tegal harus diupayakan peningkatan per-kembangan teknologi, peningkatan per-tumbuhan ekonomi dengan memperluas lapangan pekerjaan untuk peningkatan pendapatan keluarga, peningkatan pendapatan 
masyarakat secara umum dan pendapatan pemerintah kota Tegal.

Untuk dapat mencapai tujuan pembangunan di kota Tegal, maka dalam implementasinya senantiasa dilaksanakan secara menyeluruh, berencana, bertahap, terarah, terpadu dan ber-kesinambungan untuk memacu ter-wujudnya peningkatan kesejahteraan masyarakat yang tetap berlandaskan pada sendi-sendi keadilan sosial. Keterkaitan antara pembangunan prasarana dan sarana dengan struktur kemampuan masyarakat merupakan suatu dimensi penglihatan yang baru yang tidak hanya ditujukan pada perbaikan fisik prasarana dan sarana perkotaan tersebut, tetapi pada upaya memberdayakan masyarakat dalam segi memperluas lapangan pekerjaan dan meningkatkan pendapatan keluarga dan juga pemerintah kotanya.

Sejalan dengan kebijaksanaan otonomi daerah yang semakin memberikan peran kepada daerah untuk dapat lebih memacu derap pembangunan, tentunya dibutuhkan perencanaan ter-hadap kebijakan pemerintah kota untuk melakukan pembangunan yang baik dan cermat, serta diperlukan acuan kegiatan yang diharapkan dapat lebih terkoordinir, berhasil guna dan berdaya guna serta tepat dan terarah pada sasaran. Oleh karena itu salah satu kawasan yang berada di pusat kota Tegal yaitu di jalan Pancasila Kota Tegal diarahkan untuk dapat dikembangkan sebagai sentra wisata bisnis yaitu pusat kegiatan Pedagang Kaki Lima yang menjalankan aktivitas perdagangan barang, jasa dan hiburan yang lokasi usaha berada disekitar lalu lalang konsumen dengan segala kompleksitasnya. Pedagang Kaki Lima merupakan salah satu alternative pemecahan masalah yang paling sederhana yang muncul dari pemikiran sekelompok masyarakat untuk bertahan hidup dan membantu para ter-PHK dan angkatan kerja baru untuk memperoleh penghasilan yang halal sehingga mengurangi pengangguran. Jika sementara para penyelenggara pemerintahan mempunyai kewajiban untuk menciptakan kesejahteraan rakyatnya berdasarkan demokrasi ekonomi maka dengan adanya kebijakan pemerintah kota terhadap perencanaan lahan bagi PKL diharapkan dapat memberdayakan masyarakat dan meningkatkan pendapatan ekonomi masyarakat.

Diarahkannya Jalan Pancasila sebagai kawasan sentra wisata kuliner karena adanya dasar pemikiran :

i. Keunikan Jalan Pancasila dimaksudkan sebagai pelengkap ( komplemen ) dari program Pemerintah Kota Tegal " Tegal Laka-Laka",

ii. Terletaknya empat bangunan monumental ( stasiun K.A, Kantor Biro/ UPS, Gedung PDAM dan Mesjid Agung ) serta adanya Taman Poci dan Alun-Alun sebagai Brand Mark Kota Tegal yang merupakan daya tarik tersendiri bagi masyarakat Kota Tegal dan sekitarnya.

Pemerintah Kota Tegal diharapkan dapat menghasilkan suatu kebijakan untuk mengembangkan, menata dan membina para Pedagang Kaki Lima yang terletak di sekitar kawasan jalan Pancasila dan alun-alun 
Kota Tegal yang nantinya Pedagang Kaki Lima itu sendiri dapat memberikan kontribusi yang baik terhadap Pendapatan Asli Daerah. Yang jelas Pedagang Kaki Lima mempunyai potensi yang sangat besar dan dapat dimanfaatkan sebagai penghias kota jika ditata dengan baik. Pedagang Kaki Lima juga menyimpan potensi pariwisata dan dapat menjadi pembentuk estetika kota jika didesain dengan baik. Jika pemerintah dan lembaga masyarakat lainnya mampu menata dan membina Pedagang Kaki Lima di kawasan jalan Pancasila dan alun-alun Kota Tegal, maka dampak positifnya dapat dirasakan oleh seluruh masyarakat.

\section{B. PERMASALAHAN}

Berdasarkan uraian di atas, masalah yang akan dikaji dalam penelitian ini dirumuskan sebagai berikut : " Bagaimana Kelayakan Penataan Tempat Berusaha Bagi Pedagang Kaki Lima (PKL) dan Asongan di kawasan Jalan Pancasila dan alunalun Kota Tegal ?"

\section{Kerangka Teroritik}

Pemerintah Daerah, baik kota maupun metropolitan secara tipikal harus menangani enam sektor perkotaan yang saling berhubungan, yaitu per-tanahan, lingkungan, infrastruktur, perumahan, fasilitas sosial dan pembangunan ekonomi. (Nurmandi , 2006)

Pertumbuhan serta perkembangan suatu kota yang tidak selaras dengan tuntutan pemenuhan kebutuhan masyarakat kota secara sehat dan nyaman, menyebabkan perkembangan pembangunan kota yang sulit untuk dikontrol dan dikendalikan Kesulitan tersebut menyangkut tiga hal :

- Pertama, tidak tertibnya penggunaan ruang kota yang secara keseluruhan kurang mendukung optimasi pemanfaatan lahan di perkotaan.

- Kedua, menurunnya optimasi pelayanan prasarana kota seperti prasarana transpotasi, air bersih, drainase, listrik dan sebagainya, yang akumulatif menurunkan kualitas dan kemampuan kehidupan masyarakat kota.

- Ketiga, menurunnya arsitektur bangunan dan landskap kota, sehingga mengurangi keindahan penampilan ruang kota atau citra kota secara keseluruhan.( Nurmandi , 2006)

Dengan adanya keterbatasan sumber daya seperti tersebut diatas, maka diperlukan suatu usaha yang terencana dalam pengelolaan terhadap management perkotaan.

Management perkotaan (urban management) merupakan pendekatan kontemporer untuk menganalisa permasalahan perkotaan sekarang ini. Lea dan Courtney membedakan dua pendekatan management perkotaan, yaitu pendekatan problemoriented teknokratis dan pendekatan ekonomi politik struktural. Pendekatan pertama lebih memfokuskan pada peningkatan kinerja lembaga-lembaga yang ada dalam memecahkan masalah perkotaan, sedangkan pendekatan kedua lebih memfokuskan pada akar permasalahan perkotaan dalam konteks struktur ekonomi politik nasional dan internasional (Nurmandi 2006) 
Dalam setiap pembangunan , perlu adanya suatu analisa perimbangan antara biaya dan keuntungan yang akan diperoleh, untuk mendapatkan suatu hasil yang optimal. Tata pemerintahan kota terutama berperan dalam perencanaan, management, dan kebijakan dalam melahirkan perundangundangan. Namun tantangan pemerintah kota saat ini adalah membuat kerjasama dengan masyarakat selaku pemilik sekaligus pelaku pembangunan serta pihak swasta. Pemerintah kota diharapkan juga mampu mempertahankan nilai-nilai sosial dan budaya masyarakat setempat dalam menyelesaikan berbagai permasalahan sosial dan ekonomi.

Di dalam konteks pembangunan, paradigma merupakan suatu konsep / cara berfikir yang oleh kelompok pakar diakui kebenarannya sebagai hal yang dapat diaplikasikan untuk memecahkan permasalahan. Kesahihan paradigma sangat tergantung oleh ruang, waktu, perkembangan ilmu pengetahuan, teknologi, sosial, ekonomi dan kultural. ( Yunus, 2005 )

Perencanaan tata ruang kota yang terintegrasi sangat dipengaruhi beberapa faktor pembangunan kota diatas. Pemerintah kota memegang peran yang strategis sebagai perantara masyarakat sebagai stakeholders dan pihak swasta sebagai pemodal.

Kota Tegal merupakan kota yang saat ini mengalami perkembangan yang sangat pesat. Perkembangan Kota Tegal saat ini ditinjau dari aspek pergerakan baik penduduk maupun barang, serta dengan semakin bertambahnya pusat- pusat perdagangan, menyebabkan makin jauhnya pergerakan yang harus ditempuh

Sesuai dengan Peraturan Daerah Kota Tegal Nomor 05 Tahun 2002 yang merupakan perubahan Perda Nomor 11 Tahun 2001 Tentang Retribusi Pemakaian Kekayaan Daerah :

Pasal 1 huruf (e) disebutkan bahwa kekayaan daerah adalah kekayaan yang dimiliki, dikuasai dan atau dikelola oleh Pemerintah Daerah yang terdiri dari tanah, bangunan, alat berat, laboratorium, kesehatan masyarakat veterinair dan kesehatan hewan serta kekayaan daerah lainnya yang dimungkinkan dipungut retribusi.

Pasal 1 huruf g : Pemakaian Kekayaan Daerah adalah tindakan orang atau badan untuk memanfaatkan kekayaan daerah.

Pasal 1 huruf h : Retribusi Pemakaian Kekayaan Daerah yang selanjutnya disebut retribusi adalah pembayaran kepada pemerintah daerah atas pemakaian kekayaan daerah.

Dalam rangka reformasi kebijakan, perlu dilakukan perubahan cara pandang dalam membangun prasarana dan sarana perkotaan. Dimasa yang akan datang kita harus membangun kemandirian kota dalam pembangunan semua kebutuhan akan pelayanan perkotaan yang diperlukan masyarakatnya.

Perubahan cara pikir ini tidak sekedar ditujukan pada perbaikan fisik prasarana dan sarana perkotaannya, tetapi pada upaya memberdayakan 
masyarakat kota dalam segi memperluas lapangan pekerjaan dan peningkatan pendapatan baik keluarga maupun pemerintah kotanya.

Krisis multidimensi yang terjadi menimbulkan berbagai masalah dalam berbagai sektor kehidupan sosial masyarakat. Sulitnya mencari pekerjaan, banyaknya karyawan yang di PHK karena perusahaan tidak mampu lagi membayar gaji karyawannya merupakan kenyataan yang dirasakan akibat terpuruknya roda perekonomian kita. Sementara kebutuhan menghidupi anak dan istri, membayar sewa rumah, membayar SPP sekolah anak merupakan beban tetap yang harus ditanggung oleh sebuah keluarga. Pe-mecahan masalah yang paling sederhana yang muncul dari pemikiran sekelompok masyarakat kecil untuk bertahan hidup antara lain adalah dengan berjualan., mencari sedikit keuntungan dengan menjajakan berbagai jenis barang, makananan atau minuman. Sekelompok masyarakat inilah yang sekarang lebih dikenal dengan sebutan Pedagang Kaki Lima ( PKL ).

Dalam kamus Bahasa Indonesia memang belum dikenal definisi tentang Pedagang kaki Lima (PKL), namun tidak berlebihan apabila PKL ini diartikan sebagai suatu bentuk usaha informal yang dilakukan oleh seseorang / badan / lembaga dengan menjual barang atau produk dagangan yang tidak memiliki tempat usaha permanent dan sewaktuwaktu dapat berpindah-pindah tempat untuk menjajakan barang dagangannya.

Disamping itu adapula istilah Pedagang kaki Lima yang menyatakan berasal dari orang yang berdagang dengan menggelar dagangannya dengan menggunakan bangku / meja yang berkaki empat kemudian jika ditambah dengan sepasang kaki pedagangnya maka menjadi berkaki lima atau orang yang melakukan kegiatan usaha untuk maksud memperoleh penghasilan yang sah, di-lakukan secara tidak tetap dengan kemampuan yang terbatas, berlokasi di-tempat atau pusat-pusat konsumen. (Jurnal.Rukmana,2005)

Pedagang Kaki Lima ( PKL) dapat didefinisikan juga sebagai orang / pedagang golongan ekonomi lemah yang kreatif dan mandiri dengan modal seadanya, relative kecil untuk menjalankan aktivitas perdagangan barang atau jasa dan lazimnya lokasi usaha berada disekitar lalu lalang konsumen dengan menempati berkios yang sangat kecil atau meja atau menggunakan gerobak atau menggelar tikar. (jurnal, Rukmana, 2005)

Kepopuleran Pedagang Kaki Lima (PKL) dapat dilihat dalam arti positif dan dapat dilihat juga dalam arti yang negatif, yang jelas PKL memiliki cirri-ciri antara lain;

a) kegiatan usaha tidak terorganisir dengan baik

b) sebagian besar PKL tidak memiliki izin usaha

c) jika ditinjau dari sudut waktu dan tempat, seolah-olah PKL belum teratur

d) mereka melakukan aktifitas selalu dengan mendekati konsumennya .

Sebagai wiraswasta / wirausaha / entrepreneur, PKL merupakan potensi pembangunan. Dari sisi positifnya maka 
profesi PKL merupakan salah satu alternative yang membantu para ter PHK dan angkatan kerja baru untuk mem-peroleh penghasilan yang halal sehingga mengurangi pengangguran. Kegiatan yang dilakukan oleh PKL tersebut merupakan suatu kegiatan bisnis yang dijabarkan sebagai suatu kegiatan ekonomi yang terjadi dimana dalam kegiatan ini terjadi tukar menukar, jual beli, mem-produksi memasarkan, bekerja mem-pekerjakan, dan interaksi manusiawi lainnya (Bertens;2000)

Jika sementara para penyelenggara pemerintahan mempunyai kewajiban untuk menciptakan kesejahteraan rakyat-nya berdasarkan demokrasi ekonomi maka dengan adanya lahan pekerjaan berupa PKL berarti pemerintah sudah cukup terbantu dengan profesi yang satu ini.

Dari sisi keberadaan PKL yang menjamur ,bila dilihat dari keindahan , ketertiban maupun keteraturan dalam sebuah tata kota memang tidak enak dipandang mata, semrawut, kumuh bahkan dapat mengganggu arus lalu lintas atau menjadi sebab kemacetan lalu lintas yang akhirnya dapat merugikan kepentingan umum.

Pemerintah kota diupayakan untuk mampu mengembangkan konsep membuat suatu kebijakan untuk menjadikan lahan yang terletak di jalan Pancassila Kota Tegal sebagai kawasan sentra wisata kuliner yaitu pusat kegiatan bagi PKL dengan menata dan membinanya selain untuk meningkatkan ekonomi keluarga dan pemerintah kota juga diharapkan dapat dimanfaat- kan sebagai penghias kota jika ditata dengan baik dan sebagai potensi pariwisata yang dapat membentuk estetika kota jika didesain dengan baik .

Dinamika usaha dan pembangunan kota sebagai usaha untuk menciptakan kesempatan kerja dan peningkatan pen-dapatan masyarakat serta pemerintah kota tersebut ternyata berdampak multidimensi pada bidang yang lain yaitu perilaku lalu lintas, sosial budaya, hukum, lingkungan, pengelolaan asset pemerintah , dan lainnya.

Dipandang dari Undang-undang Lalu Lintas Nomor 22 Tahun 2009 sejauh ini dari kelancaran lalu lintas di kota Tegal masih belum menampakkan per-masalahan yang serius. Namun demikian bisa dikatakan bahwa sistim pengaturan management lalu lintasnya belum ber-jalan dengan baik, hal ini disebabkan karena belum terintegrasinya antara institusi pengambil kebijakan yang ber-hubungan dengan management lalu lintas perkotaan dan penggunaan asset kekayaan daerah, sebagai contoh sistim pemasangan baliho / reklame yang tidak sesuai dengan tempat peruntukannya sehingga mengganggu pengguna jalan raya , sebagai contoh lain adanya pembangunan gedung swalayan yang mengabaikan adanya amdal lalu lintas sehingga terjadi keruwetan dan kemacetan lalu lintas di sekitarnya.

Sistim pengaturan management lalu lintas Kota Tegal bahkan secara umum dapat dikatakan belum tertata dengan baik. Hal ini bisa dilihat pada beberapa kondisi diantaranya sebagai berikut : 
1. masih bercampurnya lalu lintas kendaraan mekanik dan non mekanik dengan berbagai kecepat-an dengan pejalan kaki pada be-berapa ruas jalan utama

2. dipergunakannya badan jalan dan trotoar untuk kegiatan aktivitas pedagang kaki lima

3. parkir on the road yang belum tertata dengan baik

4. belum tersedianya fasilitas taman parkir yang tertata dengan baik pada beberapa pusat kegiatan

5. belum ada fasilitas hiburan keluarga yang murah, dan aman yang terintegrasi dengan pusat kegiatan perdagangan

6. komunitas manusia yang beraktifitas disuatu tempat yang menimbulkan bangkitan lalu lintas perlu pengaturan mengenai pe-nyebarannya.

Pengembangan jalan sebagai sarana lalu lintas nampaknya akan memberi kemudahan - kemudahan masyarakat pe-makai jalan untuk mengadakan kegiatan sehari-hari dalam menunjang aktifitasnya, akan tetapi tentunya dipihak lain akan membawa akibat-akibat per-masalahan yang semakin kompleks. Permasalahan lalu lintas tersebut dalam banyak hal disebabkan oleh berbagai faktor dan yang terpenting adalah faktor pemakai dan pengguna jalan itu sendiri. Selanjutnya permasalahan lalu lintas ini akan selalu ada dan terus berkembang, karena permasalahan yang dihadapi tidak hanya menyangkut segi teknologi saja, tetapi menyangkut banyak hal, meliputi segi ekonomi, sosial budaya, hukum, lingkungan bahkan aspek politik.
Oleh karena itu pemerintah kota hendaknya mempunyai keahlian dapat mewujudkan kemampuan daerah dan kotanya untuk menyelenggarakan management pembangunban kota yang terpadu dengan ciri-ciri :

1. Mampu menyusun prioritasprioritas pembangunan kotanya dalam suatu program pembangunan kota yang terpadu

2. Mampu menyelenggarakan tugastugas pemerintahan terutama adalah membangun prasarana dan sarana perkotaan dan menciptakan suasana aman (urban security) dan kepastian hukum (legal security), serta mengelola sumber daya pembangunan seperti keuangan dan ruang / lahan kota

3. Mampu memberdayakan masyarakat kota dalam meningkat-kan kesempatan kerja serta pen-dapatan keluarga, yang dapat me-ningkatkan daya belinya guna me-menuhi kebutuhannya secara se-imbang untuk kesejahteraan yang semakin meningkat, melalui pe-mbangunan ekonomi lokal yang terkait dengan pembangunan ekonomi nasional dan berdaya saing dalam perekonomian global

4. Mampu memetik hasil dari pembangunan ekonomi lokal dan ekonomi masyarakat kota sehingga pendapatan asli daerah terus me-ningkat agar dapat meningkatkan kemampuan kota dalam menjaga keberlangsungan penyediaan pra-sarana dan sarana yang diperlu-kan sesuai dengan per-kembangan dan pertumbuhan kebutuhan masyarakat

5. Mampu menyelenggarakan semua hal diatas dengan menumbuhkan kemampuan peran serta 
masyarakat dalam memutuskan strategi dan melaksanakan pembangunan kotanya dengan mewujudkan citra pemerintahan yang terbuka, bersih, berwibawa dan mampu memberikan masukan kepada pimpinan dalam wujud gagasan-gagasan pembangunan kota yang bermutu dan professional ( jurnal, Arif, 2005 )

Upaya menciptakan dan menyelenggarakan semua tugas pembangunan sarana dan prasarana tersebut, diperlukan sumber daya manusia yang tangguh yang terdiri dari :

1. Tenaga professional yang memiliki keahlian dalam semua sektor pem-bangunan sarana dan prasarana perkotaan.

2. Tenaga professional yang memiliki wawasan keterpaduan pembangunan prasarana perkotaan

3. Tenaga professional yang memiliki keahlian dalam bidang-bidang khusus seperti penyusunan Rencana Induk, Studi Kelayakan. Management Proyek, Supervisi Pelaksanaan Proyek, Penyusunan Program Pembangunan Prasarana Kota Terpadu ( P3KT ), Penyusunan Program Jangka Menengah ( PJM ), Strategi Pembangunan Perkotaan, dan Penataan Ruang Perkotaan.

\section{Metodologi Penelitian}

Penelitian ini merupakan penelitian eksploratif yang menggunakan metode pendekatan kualitatif, yaitu melalui survey pada obyek penelitian Pedagang Kaki Lima yang berlokasi di jalan Pancasila dan Alunalun Kota Tegal .

Metode yang digunakan dalam Feasibility Study Pengembangan Sentra
Wisata Kuliner di Kawasan Jalan Pancasila dan Alun-alun Kota Tegal adalah survey dan pengamatan (observasi) di lapangan. Survey lapangan dan observasi dilakukan untuk mem-peroleh data potensi yang ada dan kondisi eksisting kawasan Jalan Pancasila dan Alun-alun Kota Tegal.

Berdasarkan sifat data, maka data dikelompokkan menjadi data primer dan data sekunder. Data primer yang diperoleh meliputi: Wawancara langsung (dan kuesioner) dengan pedagang kaki lima, di Jalan Pancasila dan Alun-alun Kota Tegal, Sedangkan data sekunder meliputi : (1) Pengumpulan peraturan atau ketentuan-ketentuan perundangan yang berlaku, Peraturan Daerah, Surat Keputusan Walikota, serta keputusankeputusan intern yang diterbitkan oleh Daerah.

\section{Metode Analisis}

Data yang diperoleh akan diklasifikasikan, dianalisis dan diolah sesuai dengan tahapan dan jenis pekerjaan yang akan dilaksanakan serta dianalisis kelayakannya menurut aspek sosial, ekonomi dan lingkungan.

1. Pengukuran variabel

Pengukuran variabel dilakukan dengan menggunakan skala likert dengan penilaian sangat tidak setuju dengan skor 1 sampai sangat setuju dengan skor 5.

2. Uji Validitas

Uji Validitas digunakan untuk mengukur sejauh mana ketepatan dan kecermatan suatu alat ukur dalam melakukan fungsinya. Cara yang digunakan adalah dengan analisis item, dimana setiap nilai 
yang ada pada setiap butir pertanyaan dikorelasikan dengan nilai total seluruh butir per-tanyaan untuk suatu variabel dengan menggunakan rumus Korelasi produk moment:

$$
\mathrm{r}=\frac{n(\Sigma \mathrm{XY})-(\Sigma X \Sigma Y)}{\sqrt{\left[\left\{n \Sigma \mathrm{X}^{2}-(\Sigma \mathrm{X})^{2}\right\}\left\{n \Sigma Y^{2}-(\Sigma Y)^{2}\right\}\right]}}
$$

Keterangan :

$$
\text { rXiX }=\text { Koefisien korelasi }
$$
pertanyaan dengan total

$\mathrm{n}=$ Jumlah responden

$\mathrm{X}=$ Skor pertanyaan nomor i

$\mathrm{Y} \quad=\quad$ Skor total tetap

Dengan tingkat keyakinan 95 persen, maka bila :

$r>r$ tabel, berarti item tersebut dinyatakan diterima (valid)

$\mathrm{r} \leq \mathrm{r}$ tabel, berarti item tersebut dinyatakan tidak diterima (invalid)

3. Uji Reliabilitas (keandalan)

Uji keandalan dimaksudkan untuk mengetahui konsistensi alat ukur dalam penggunaannya, atau dengan kata lain alat ukur tersebut mempunyai hasil konsisten apabila digunakan berkali-kali pada waktu yang berbeda. Untuk uji reliabilitas ini digunakan teknik Alpha Cronbach, dengan rumus sebagai berikut:

$$
\mathrm{r}=\left[\frac{\mathrm{k}}{\mathrm{k}-1}\right]\left[1-\frac{\sum \sigma_{\mathrm{b}}^{2}}{\sigma_{\mathrm{t}}^{2}}\right]
$$

Keterangan:

$r=$ reliabilitas

instrumen

$\mathrm{k}=$ banyak butir

pertanyaan

$\sigma_{t}^{2}=\quad$ varians total $\sum \sigma_{b}^{2}=\quad$ jumlah varian butir.

\section{E. ANALISIS KUESIONER PKL ALUN-ALUN KOTA TEGAL \\ 1. Aspek Ekonomi}

Semakin merebaknya jumlah PKL sebenarnya dapat memberikan keuntungan tersendiri bagi pihak Pemerintah Kota Tegal. Apalagi apabila PKL yang ada di Jl. Sebayu, mempunyai kesadaran untuk membayar reribusi kepada Pemerintah Kota Tegal. Hal ini tentu dapat menjadi salah satu pos anggaran untuk pendapatan asli daerah (PAD). Dengan adanya retribusi dari PKL inilah Kota Tegal mampu mengembangkan kotanya. Sehingga diperlukan upaya - upaya untuk mengatur PKL namun tidak menganggap rendah keberadaan PKL agar kas daerah dari retribusi dapat semakin meningkat serta dapat memenuhi target yang telah di-tetapkan. Jika PKL itu sendiri semakin meningkat taraf kehidupannya maka retribusi yang dibayarkan akan terasa ringan dan PKL tersebut tidak terbebani dengan pungutan wajib tersebut.

Segala upaya telah dilakukan oleh para aparat melalui operasi yustisi, penertiban dilakukan untuk kepentingan bersama dan demi menjaga kenyamanan kota. Pemerintah kota tidak sekedar menggusur tanpa adanya solusi, tidak sekedar mengusir tanpa adanya alternatif untuk berjualan atau membuka usaha lain. Semestinya dalam hal ini relokasi menjadi alternatif yang terbaik dalam penanganan PKL, tapi kenyataanya alternatif ini kurang mendapat tanggapan. 
Berdasarkan hasil obbservasi ternyata masih ada tempat - tempat yang belum dapat dijangkau oleh aparat dalam upaya penegakan peraturan serta masih banyak pedagang yang belum dapat diatur karena mereka sudah terbiasa berjualan di tempat tersebut. Hal ini dikarenakan sikap para pedagang kaki lima yang keras untuk tetap menempati lokasi yang dilarang oleh pemerintah kota. Mereka tidak mau dipindahkan lantaran mereka sudah nyaman dengan tempat yang telah mereka tempati, karena para PKL berjualan hanya pada tempat-tempat yang ramai dan strategis.

Sikap kontraproduktif yang ditunjukkan oleh sebagian PKL tersebut jelas kurang dapat diterima. Namun setelah melalui beberapa pendekatan yang dilakukan oleh pemerintah kota Tegal maka sesuai hasil pengisian kuesioner didapati bahwa ternyata mayoritas responden yaitu 55,07\% menjawab "setuju" pada pernyataan bahwa lokasi berjualan yang baru (kawasan sentra kuliner jl. Pancasila) sangat strategis karena mempunyai daya tarik bagi pengunjung.

Temuan ini memberi arti bahwa para PKL di jl. Sebayu berharap agar pemerintah segera mengeluarkan regulasi yang dapat menjamin kelangsungan mata pencaharian mereka sebagai PKL. Pertimbangannya tentu saja tidak terlepas dari lokasi berdagang yang dinilai strategis.
Tabel. 1

Lokasi berjualan yang baru sangat strategis karena mempunyai daya tarik bagi pengunjung

\begin{tabular}{|c|l|c|c|}
\hline No & $\begin{array}{l}\text { Kategori } \\
\text { Jawaban } \\
\text { Responden }\end{array}$ & Frekuensi & Prosentase \\
\hline 1 & Sangat Setuju & 20 & 28,99 \\
\hline 2 & Setuju & 38 & 55,07 \\
\hline 3 & Ragu-ragu & 9 & 13,04 \\
\hline 4 & Tidak Setuju & 2 & 2,90 \\
\hline 5 & $\begin{array}{l}\text { Sangat Tidak } \\
\text { Setuju }\end{array}$ & 0 & 0 \\
\hline & TOTAL & 69 & 100 \\
\hline
\end{tabular}

Sumber : observasi 2012

Sikap akomodatif Pemerintah Kota Tegal terhadap keberadaan PKL jelas memberi angin segar bagi PKL. Dalam hal ini rencana penataan PKL di kawasan jl. Sebayu (alun-alun) dan kawasan Jl. Pancasila diperkirakan akan berdampak positif bagi kehidupan para PKL. Kawasan tersebut, yang rencananya menjadi sentra wisata kuliner kota Tegal merupakan kawasan yang ramai pengunjung dan lokasinya strategis.

Berdasarkan hasil survey diketahui sebanyak 62,32 \% responden menjawab "setuju" terhadap pernyataan bahwa dengan keramaian di lokasi berjualan yang baru, membuat hasil usaha mampu memenuhi kebutuhan keluarga. Kondisi ini semestinya dimaklumi mengingat keadaan ekonomi keluarga PKL yang sangat bergantung pada aktifitas perdagangan sebagai satu-satunya mata pencaharian. Dengan demikian maka sudah sepantasnya para PKL menyambut positif rencana sentra wisata kuliner di jl. Pancasila ini. 
Tabel. 2

Keramaian di lokasi berjualan yang ditata baru, membuat hasil usaha mampu memenuhi kebutuhan keluarga

\begin{tabular}{|l|l|c|c|}
\hline No & $\begin{array}{l}\text { Kategori } \\
\text { Jawaban } \\
\text { Responden }\end{array}$ & Frekuensi & Prosentase \\
\hline 1 & Sangat Setuju & 13 & 18,84 \\
\hline 2 & Setuju & 43 & 62,32 \\
\hline 3 & Ragu-ragu & 10 & 14,49 \\
\hline 4 & Tidak Setuju & 3 & 4,35 \\
\hline 5 & $\begin{array}{l}\text { Sangat Tidak } \\
\text { Setuju }\end{array}$ & 0 & 0 \\
\hline & TOTAL & 69 & 100 \\
\hline
\end{tabular}

Sumber : Observasi, 2012

Keberadaan PKL di kota-kota besar dapat menjadi simpul-simpul ekonomi yang turut menentukan hidup dan matinya urat nadi ekonomi suatu daerah. Pada kawasan-kawasan tertentu bahkan terjadi per-putaran rupiah yang cukup tinggi hingga mencapai ratusan juta rupiah setiap hari/ malamnya. Hal ini tentu cukup memberi prospek cerah bagi PKL maupun pihak pemerintah kota apabila dibarengi dengan penataan PKL yang apik dan bijaksana.

Mengacu pada perkembangan yng semakin baik tersebut, hasil survei menunjukkan bahwa sebanyak 56,52\% responden PKL di Jl. Sebayu (alun-alun) menjawab "setuju" apabila usaha yang dijalankan di lokasi yang baru ( kawasan sentra wisata kuliner jl. Pancasila) akan terus mengalami perkembangan karena pengunjung yang datang akan semakin banyak. Kondisi ini tentu akan berimbas positif bagi tingkat pendapatan para PKL.
Tabel. 3

Usaha yang dijalankan di lokasi yang baru akan terus mengalami perkembangan karena pengunjung yang datang akan semakin banyak

\begin{tabular}{|l|l|c|c|}
\hline No & $\begin{array}{c}\text { Kategori Jawaban } \\
\text { Responden }\end{array}$ & Frekuensi & Prosentase \\
\hline 1 & Sangat Setuju & 11 & 18,84 \\
\hline 2 & Setuju & 48 & 56,52 \\
\hline 3 & Ragu-ragu & 9 & 17,39 \\
\hline 4 & Tidak Setuju & 1 & 7,25 \\
\hline 5 & Sangat Tidak Setuju & 0 & 0 \\
\hline & TOTAL & 69 & 100 \\
\hline
\end{tabular}

Sumber : Observasi 2012

Selama ini muncul kesan bahwa pengaturan PKL hanya berkesan memindahkan pedagang saja dari satu tempat ke tempat lain tanpa adanya tindak lanjut untuk menyiapkan sarana dan prasarana terkait dengan sosialisasi yang kurang efektif karena informasi yang disampaikan petugas sebatas lokasi baru saja tanpa menjelaskan lebih rinci mengenai infrastruktur lokasi baru.

Berdasarkan hasil wawancara yang secara tidak terstruktur, PKL menyatakan bahwa dalam berlokasi mereka tidak mempertimbangkan aspek ketersediaan prasarana penunjang seperti air, listrik, persampahan dan WC. Tidak setiap PKL membutuhkan prasarana penunjang ter-sebut tergantung dari waktu ber-dagang, sarana dagang yang digunakan serta jenis barang dagangan. Sebagai contoh seperti PKL yang berjualan pada pagi hingga sore hari. Mereka tidak memerlukan listrik untuk penerangan. Atau PKL non makanan yang tidak membutuhkan air bersih untuk mencuci seperti yang dibutuhkan oleh PKL makanan. 
PKL-PKL yang membutuhkan prasarana penunjang, dapat menyediakan sendiri. Seperti prasarana penunjang be-rupa kebutuhan air. Dalam penyediaannya, PKL dapat membawa dari rumah jika tempat tinggal mereka relatif dekat atau membeli dari jasa penjual air yang biasa menjual ke PKL-PKL. Sedangkan untuk listrik, mereka menyambung aliran listrik dari masyarakat sekitar atau menggunakan petromak. Sedangkan WC, biasanya mereka menumpang di kegiatan utama yang ada di sekitarnya. Prasarana per-sampahan biasanya juga memanfaatkan TPS pada kegiatan utama, sebagai kompensasinya membayar uang kebersihan.

Berkaitan dengan penyediaan sarana dan prasarana, maka penataan PKL di Jalan Pancasila dan alun-alun Kota Tegal jelas akan memberikan banyak keuntungan bagi para PKL. Sesuai dengan hasil survey menunjukkan bahwa sebanyak 63,77\% responden "setuju" bahwa biaya produksi dapat ditekan karena di tempat baru tersedia listrik, air, tempat sampah dan sebagainya.

\section{Tabel.4}

Biaya produyksi dapat ditekan karena di tempat baru tersedia listrik, air, tempat sampah dan sebagainya

\begin{tabular}{|l|l|c|c|}
\hline No & $\begin{array}{l}\text { Kategori } \\
\text { Jawaban } \\
\text { Responden }\end{array}$ & Frekuensi & Prosentase \\
\hline 1 & Sangat Setuju & 14 & 20,29 \\
\hline 2 & Setuju & 44 & 63,77 \\
\hline 3 & Ragu-ragu & 9 & 13,04 \\
\hline 4 & Tidak Setuju & 2 & 2,90 \\
\hline 5 & $\begin{array}{l}\text { Sangat Tidak } \\
\text { Setuju }\end{array}$ & 0 & 0 \\
\hline & TOTAL & 69 & 100 \\
\hline
\end{tabular}

Sumber : Observasi 2012

Sejauh ini wisata kuliner kota Tegal masih banyak terpusat di kawasan
"Tegal Laka-laka". Dengan wacana relokasi PKL di Jalan. Pancasila dan menjadikannya sebagai sentra wisata kuliner tentunya pemerintah kota Tegal akan segera melengkapi semua fasilitas yang di-perlukan. Hal ini berarti bahwa tingkat kenyamanan, keamanan dalam ber-belanja menjadi prioritas utama. Apabila syarat ini terpenuhi maka bisa dipastikan tingkat kunjungan masyarakat akan terus mengalami peningkatan.

Data yang berhasil dihimpun dari lapangan menujukkan bahwa sebanyak 69,57\% responden menjawab "setuju" terhadap pernyataan bahwa pembeli akan merasa betah dan akan datang kembali (retensi) untuk membeli karena di lokasi yang baru terasa lebih nyaman sebagai tempat bersantai. Temuan ini mencerminkan sebuah optimism dari para PKL alun-alun dan jalan. Pancasila Kota tegal merasa yakin nantinya pengunjung / pembeli akan semakin meningkat.

Tabel. 5

Pembeli akan merasa betah dan akan datang kembali (retensi) untuk membeli karena di lokasi yang baru terasa lebih nyaman sebagai tempat bersantai

\begin{tabular}{|l|l|c|c|}
\hline No & $\begin{array}{c}\text { Kategori Jawaban } \\
\text { Responden }\end{array}$ & Frekuensi & Prosentase \\
\hline 1 & Sangat Setuju & 14 & 20,29 \\
\hline 2 & Setuju & 48 & 69,57 \\
\hline 3 & Ragu-ragu & 5 & 7,25 \\
\hline 4 & Tidak Setuju & 2 & 2,90 \\
\hline 5 & Sangat Tidak Setuju & 0 & 0 \\
\hline & TOTAL & 69 & 100 \\
\hline
\end{tabular}

Sumber : Observasi 2012

Ada banyak hal yang dijadikan alasan bagi PKL untuk berdagang di suatu tempat tertentu. Selain pada aspek lokasi yang strategis sehingga ramai dikunjungi pembeli, ada juga 
aspek keamanan dan kenyamanan yang tak kalah pentingnya. Tidak jarang demi terjaminnya aspek keamanan para PKL ini "ikhlas" untuk membayar jasa keamanan pada oknum tertentu. Namun berdasarkan pengamatan di lapangan Jl. Sebayu (alun-alun) maupun Jl. Pancasila para pedagang merasa aman, apalagi bila nanti dijamin oleh pemerintah kota melalui sentra wisata kuliner di jl. Pancasila.

Berdasarkan hasil pengisian kuesioner ternyata terdapat $68,12 \%$ responden yang menjawab 'setuju" terhadap pernyataan bahwa bila kelak dipindahkan ke lokasi lain sekitar alunalun, maka akan lebih strategis, nyaman dan aman dibandingkan tempat berjualan saat ini. Sikap yang ditunjukkan oleh para responden PKL di jl. Sebayu menjadi indikasi jelas adanya sebuah penerimaan bahwa nantinya prospek dagang mereka lebih baik di. Jl. Pancasila daripada se-belumnya.

Tabel. 6

Bila kelak dipindahkan ke lokasi lain sekitar alun-alun, maka akan lebih strategis, nyaman dan aman dibandingkan tempat berjualan saat ini

\begin{tabular}{|l|l|c|c|}
\hline No & $\begin{array}{c}\text { Kategori Jawaban } \\
\text { Responden }\end{array}$ & Frekuensi & Prosentase \\
\hline 1 & Sangat Setuju & 10 & 14,49 \\
\hline 2 & Setuju & 47 & 68,12 \\
\hline 3 & Ragu-ragu & 10 & 14,49 \\
\hline 4 & Tidak Setuju & 2 & 2,90 \\
\hline 5 & Sangat Tidak Setuju & 0 & 0 \\
\hline & TOTAL & 69 & 100 \\
\hline
\end{tabular}

Sumber : Observasi 2012

Apabila diperhatikan, kawasan alun-alun maupun kawasan jl. Pancasila me-rupakan kawasan yang sibuk di Kota Tegal. Kawasan Jl. Sebayu (alun-alun) menjadi kawasan yang sibuk karena daerah ini merupakan pusat pe- nyelenggaraan roda pemerintahan Kota Tegal. Adapun kawasan Jl. Pancasila menjadi kawasan yang ramai karena daerah ini bertepatan dengan lokasi stasiun kereta api dan juga pasar tradisional (pasar burung, pasar ikan hias, dan pasar loak) serta taman poci yang menjadi ruang publik untuk berwisata menjelang sore hari.

Dapat diperkirakan bahwa apabila rencana kepindahan PKL dari kawasan alun-alun ke kawasan Jl. Pancasila benar-benar terjadi maka kawasan ini akan menjadi lebih ramai lagi. Apalagi bila pemerintah kota Tegal menetapkan kawasan jl. Pancasila menjadi sentra wisata kuliner kota Tegal.

Berdasarkan hasil observasi didapati sebanyak 66,67\% responden menjawab "setuju" terhadap pernyataan bahwa dengan keramaian yang ada di lokasi sekarang, sudah tentu lokasi yang baru nanti akan lebih ramai.

\section{Tabel. 7}

Dengan keramaian yang ada di lokasi sekarang, sudah tentu lokasi yang baru nanti akan lebih ramai

\begin{tabular}{|l|l|c|c|}
\hline No & $\begin{array}{c}\text { Kategori Jawaban } \\
\text { Responden }\end{array}$ & Frekuensi & Prosentase \\
\hline 1 & Sangat Setuju & 8 & 11,59 \\
\hline 2 & Setuju & 46 & 66,57 \\
\hline 3 & Ragu-ragu & 14 & 20,29 \\
\hline 4 & Tidak Setuju & 1 & 1,45 \\
\hline 5 & Sangat Tidak Setuju & 0 & 0 \\
\hline & TOTAL & 69 & 100 \\
\hline
\end{tabular}

Sumber : Observasi 2012

PKL sebagai tulang punggung ekonomi masyarakat lemah, membutuhkan perhatian lebih dari pemerintah dalam hal penyelenggaraan iklim yang kondusif bagi berkembangnya usaha mereka. Pe-nyelenggaraan iklim yang kondusif bagi berkembangnya mereka akan me-ngefektifkan pengelolaan dan penataan PKL agar meningkat dan berkembang skala 
usahanya tanpa mengabaikan ketertiban, kebersihan dan keindahan kota seperti yang diatur dalam Perda Kota Tegal No.03/2008 Tentang Pengaturan Peadagang Kaki Lima

Penataan PKL di lokasi yang baru, yaitu sentra kuliner di Jl. Pancasila diyakini dapat semakin meningkatkan per-kembangan usaha PKL. Sebagian besar responden yaitu 59,42\% menyatakan "setuju'" terhadap pernyataan bahwa lokasi berjualan yang baru, akan memperlancar perkembangan usaha. Hal ini memberi makna adanya sikap optimisme dan pengharapan dari para PKL akan lebih berkembang lagi usahanya.

Tabel. 8

Lokasi berjualan yang baru, akan memperlancar perkembangan usaha

\begin{tabular}{|l|l|c|c|}
\hline No & $\begin{array}{c}\text { Kategori Jawaban } \\
\text { Responden }\end{array}$ & Frekuensi & Prosentase \\
\hline 1 & Sangat Setuju & 12 & 17,39 \\
\hline 2 & Setuju & 41 & 59,42 \\
\hline 3 & Ragu-ragu & 15 & 21,74 \\
\hline 4 & Tidak Setuju & 1 & 1,45 \\
\hline 5 & Sangat Tidak Setuju & 0 & 0 \\
\hline & TOTAL & 69 & 100 \\
\hline
\end{tabular}

Sumber : Observasi 2012

Ekspetasi atau harapan dari setiap PKL relatif sama, yaitu ingin sebuah kemajuan. Seandainya diperkenankan memilih niscaya mereka akan memilih tempat berdagang yang lebih mengutungkan usaha mereka. Dalam pandangan PKL jalan. Pancasila adalah sebuah lokasi yang cukup menjanjikan. Berdasarkan hasil survey ternyata diketahui sebanyak 65,22\% responden "setuju" terhadap pernyataan bahwa bila diijinkan, maka lebih baik memilih dipindahkan ke lokasi baru yang kondisinya lebih baik dari pada kondisi saat ini.
Tabel. 9

Relokasi dengan fasilitas lebih baik

\begin{tabular}{|l|l|c|c|}
\hline No & $\begin{array}{c}\text { Kategori Jawaban } \\
\text { Responden }\end{array}$ & Frekuensi & Prosentase \\
\hline 1 & Sangat Setuju & 14 & 20,29 \\
\hline 2 & Setuju & 45 & 65,22 \\
\hline 3 & Ragu-ragu & 8 & 11,59 \\
\hline 4 & Tidak Setuju & 2 & 2,90 \\
\hline 5 & Sangat Tidak Setuju & 0 & 0 \\
\hline & TOTAL & 69 & 100 \\
\hline
\end{tabular}

Sumber : Observasi 2012

Keberadaan PKL harus juga dipandang dari segi positif. PKL dapat menyerap angkatan kerja, retribusi yang dipungut dari PKL dapat membantu mem-berikan kontribusi kepada pemerintah daerah, dan PKL dapat membuka lapangan kerja sendiri. Selain itu PKL juga ikut serta membantu sistem ekonomi perkotaan dalam hal menciptakan rantai-rantai kegiatan ekonomi perkotaan. Itu semua akan mungkin terwujud manakala usaha yang digelar oelh PKL juga mendapat sambutan positif dari masyarakat pembeli.

Berkaitan dengan hal tersebut maka para PKL menilai bahwa besar kemungkinan jumlah pelanggan akan bertambah apabila nanti lokasi berjualan mereka benar-benar direlokasi ke Jl. Pancasila dalam sentra wisata kuliner. Sesuai dengan hasil survey diketahui sebanyak 66,67\% responden menyatakan "setuju" dengan pernyataan dalam kuesioner yang menyebutkan bahwa bila kelak dipindahkan, sangat besar kemungkinannya pelanggan akan bertambah. 
Tabel. 10

Bila kelak dipindahkan, sangat besar kemungkinannya pelanggan akan bertambah.

\begin{tabular}{|l|l|c|c|}
\hline No & $\begin{array}{l}\text { Kategori } \\
\text { Jawaban } \\
\text { Responden }\end{array}$ & Frekuensi & Prosentase \\
\hline 1 & Sangat Setuju & 12 & 17,39 \\
\hline 2 & Setuju & 46 & 66,67 \\
\hline 3 & Ragu-ragu & 9 & 13,04 \\
\hline 4 & Tidak Setuju & 2 & 2,90 \\
\hline 5 & $\begin{array}{l}\text { Sangat Tidak } \\
\text { Setuju }\end{array}$ & 0 & 0 \\
\hline & TOTAL & 69 & 100 \\
\hline
\end{tabular}

Sumber : Observasi 2012

Berdasarkan temuan-temuan dari aspek ekonomi, secara mayoritas dapat dikatakan bahwa rencana kebijakan relokasi PKL di jalan Pancasila sebagai sentra wisata kulinera Tegal.

\section{Aspek Sosial}

Ketertiban dan kenyamanan kota (tidiness and convenience) merupakan fungsi turunan terpenting dari penataan ruang kota. Tujuan utama penataan ruang kota adalah terciptanya keserasian antar fungsi kegiatan di dalam ruang kota. Penataan ruang kota ini mutlak diperlukan karena dinamika ruang kota cenderung bergerak ke arah terjadinya kompetisi ruang yang sangat potensial bagi timbulnya konflik ruang. Potensi konflik ini sudah barang tentu harus diantisipasi melalui penataan ruang publik yang baik.

Tata ruang harus dipandang sebagai upaya pemanfaatan sumberdaya ruang agar sesuai dengan tujuan untuk sebesar-besarnya kemakmuran rakyat (UU No. 5/1960 Pasal 2 ayat 3). Dengan demikian Perencanaan Tata Ruang adalah bagian yang tak terpisahkan dari tujuan pembangunan secara keseluruhan.
Awal dari proses penataan ruang adalah beranjak dari adanya kebutuhan untuk melakukan perubahan sebagai akibat dari perubahan pengelolaan maupun akibat perubahan-perubahan keadaan (peningkat-an kesejahteraan, bencana alam, per-kembangan sosial, dan lain-lain). Jadi pada dasarnya harus ada dua kondisi yang harus dipenuhi dalam perencanaan tata ruang: (1) kebutuhan masyarakat untuk melakukan perubahan atau upaya untuk mencegah terjadinya perubahan yang tidak diinginkan, (2) adanya political will dan kemampuan untuk mengimplementasikan pe-rencanaan yang disusun (Rustiadi, dkk, 2006).

Kota Tegal adalah kota pusat pertumbuhan di kawasan barat propinsi Jawa Tengah. Kondisi ini akan menyebabkan pertumbuhan dan perkembangan kota yang lebih cepat di bandingkan dengan kota - kota disekitarnya. Selain itu dengan "program" Kota Tegal sebagai kota bisnis akan menyebabkan semakin banyaknya peluang bisnis yang dapat memacu peningkatan pertumbuhan jumlah pusat-pusat perdagangan.

Pedagang Kaki Lima (PKL) merupakan kelompok tenaga kerja yang banyak di sektor informal. PKL juga memiliki potensi untuk menciptakan dan memperluas lapangan kerja, terutama bagi tenaga kerja yang kurang memiliki kemampuan dan keahlian yang memadai untuk bekerja di sektor formal karena rendahnya tingkat pendidikan yang mereka miliki.

Berdasarkan Absori et.al. dalam Kusumawijaya, (2006) Pedagang Kaki 
Lima memiliki dimensi kegiatan yang sangat kompleks, baik terkait dengan aspek 3 ekonomi, teknis, sosial, lingkungan maupun ketertiban umum. Performa penataan PKL di kawasan alun-alun dan jalan Pancasila Kota Tegal dapat dilihat dari tiga aspek penting tersebut yaitu aspek ekonomi, sosial dan hukum yang sesuai dengan konsep penataan Sutrisno et, al (2007)

Fenomena pertumbuhan Pedagang Kaki Lima (PKL) telah menjadi isu internasional karena menimbulkan potensi konflik ruang yang akan berdampak negatif bagi ketertiban dan kenyamanan kota. Konflik ruang yang ditimbulkan oleh PKL biasanya terjadi ketika PKL sudah me-nempati ruang publik kota pada tingkatan tertentu sehingga mengakibatkan ter-ganggunya fungsi ruang public tersebut.

Ketidakteraturan lokasi aktivitasnya yang diakibatkan oleh bentukan fisik yang beragam dan sering terkesan asal-asalan dan kumuh berupa kios-kios kecil dan gelaran dengan alas seadanya, menjadikan visual suatu kawasan per-kotaan yang telah direncanakan dan dibangun dengan apik, menjadi terkesan kumuh dan tidak teratur sehingga menurunkan citra suatu kawasan. Hingga pada akhirnya aktivitas PKL di dalam suatu perkotaan menyebabkan menurunnya kualitas lingkungan per-kotaan. Terkait dengan permasalahan tersebut, pemerintah sudah mencari alternative pemecahannya dengan jalan menertibkan dengan menggusur atau menata aktivitas PKL dengan mengembalikan fungsi asli dari kawasan tersebut serta merelokasi para PKL tersebut ke lokasi baru. Namun pada kenyataannya, setelah pelaksanaan relokasi, PKL kembali beraktivitas ke tempat semula bahkan jumlahnya bertambah.

Keberadaan Pedagang Kaki Lima di Kota Tegal hampir tidak mungkin di tiadakan dan keberadaanya pun sangat berpengaruh bagi perekonomian daerah. Akan tetapi, seiring dengan pertumbuhan PKL khususnya di Kota Tegal munculah berbagai masalah lingkungan yang tumbuh akibat Pedagang Kaki Lima antara lain masalah pencemaran, tata ruang yang tidak sesuai karena keberadaan PKL yang menempati kawasan yang bukan baginya misalnya di emperemper toko, taman-taman, trotoar dan lain sebagainya. Tentunya ini sangat menggangu ke-bersihan dan keindahan jalan serta menimbulkan kemacetan lalu lintas dan ketidaknyamanan pejalan kaki.

Dalam kaitan inilah maka upaya penataan PKL menjadi sangat penting dilakukan sebagai bagian dari penataan ruang kota untuk menjamin terwujudnya ketertiban dan kenyamanan kota. Hal ini diamanatkan oleh Undang-undang penataan ruang yang baru yaitu UU No.26/2007. Salah satu pasal dari UU tersebut yaitu pasal 28c menyebutkan bahwa dalam rencana tata ruang wilayah kota harus memuat rencana penyediaan dan pemanfaatan sarana dan prasarana untuk kegiatan sector informal. Secara tersirat dari pasal tersebut diamanatkan bagi pemerintah kota untuk menyediakan ruang bagi kegiatan sektor informal, diantaranya PKL. 
Secara umum bentuk penataan PKL bisa dilakukan dengan dua cara, yaitu (1) Relokasi di tempat (insitu), (2) Relokasi ke tempat yang strategis. Relokasi di tempat (insitu) bentuknya bisa berupa penataan tempat, pengaturan lokasi berjualan berdasarkan jenis dagangan, pengaturan waktu jualan (time sharing), pengaturan sarana atau tempat untuk berjualan (baik berupa tenda ataupun gerobak, dan sebagainya). Relokasi ke tempat yang strategis berupa pemindahan lokasi PKL ke tempat yang baru yang letaknya tidak jauh dari pusat perdagangan dan jasa (tempat yang ramai, mudah dikunjungi oleh konsumen) atau berupa relokasi ke suatu gedung/pasar.

Dari hasil observasi di lapangan dapat disimpulkan bahwa tipologi PKL di kawasan alun-alun dan jalan Pancasila kota kota Tegal dibedakan menjadi pe-dagang menetap, semi menetap dan keliling. PKL di Jl Pancasila merupakan jenis PKL yang menetap, sedangkan PKL di kawasan alun-alun umumnya termasuk PKL semi menetap. PKL keliling me-rupakan bagian komunitas yang terdapat di kawasan alun-alun maupun jl. Pancasila.

Pemerintah kota Tegal sedang berusaha untuk menertibkan Pedagang Kaki Lima yang berada di tempat tempat yang tidak semestinya untuk berjualan. Banyak pihak yang mendukung upaya ini dan sudah lama menunggu tindakan tegas dari aparat melalui operasi agar kota ini tidak menjadi hutan bagi para PKL. Namun, tidak sedikit pihak yang menolak dan merasa memaklumi keberadaan PKL yang rata - rata berasal dari kelompok masyarakat menengah dan kebawah.

Dalam hal ini diperlukan adanya kesadaran para PKL untuk mematuhi peraturan pemerintah, untuk menumbuhkan kesadaran para PKL supaya mereka menaati peraturan yang berlaku. Fenomena yang sekarang terjadi adalah adanya penjarahan ruang publik yaitu membuka usaha di trotoar, taman taman dan pinggir jalan Ki Gede Sebayu (kawasan alun-alun) yang digunakan untuk berjualan.

Beberapa hal yang mendasari adanya suatu pengaturan dan penertiban PKL di kawasan alun-alun yaitu :

a) Menganggu kepentingan umum terutama pejalan kaki yang tidak nyaman lagi berjalan di trotoar, karena digunakan untuk tempat berjualan dan menganggu arus lalu lintas.

b) Terkait dengan adanya revitalisasi Alun-alun.

c) Merusak keindahan kota, karena memang keberadaan PKL dapat menyebabkan lingkungan perkotaan kumuh.

Secara umum semua PKL yang ada di kawasan alun-alun dan jl. Pancasila Kota Tegal menginginkan adanya penataan agar tercipta suatu ketertiban dan kenyamanan bagi semua masyarakat Kota Tegal. Berdasarkan penelitian di lapangan ternyata sikap di kalangan PKL alun-alun Kota Tegal terhadap wacana relokasi PKL ke arah Jl. Pancasila adalah sebanyak 78,26\% responden menyikapi secara positif terhadap konsekuensi bahwa dalam perkembangannya keadaan PKL sebaiknya disesuaikan dengan per- 
kembangan tata kota yang indah, rapi, dan tertib.

\section{F. PENUTUP}

\section{Kesimpulan}

Sejauh ini keberadaan PKL di kawasan Jl. Sebayu (alun-alun) maupun PKL di Jl. Pancasila kurang tertata dengan baik, hal ini dapat dilihat dari banyaknya pedagang yang masih berjualan di tepi-tepi jalan sehingga kawasan tersebut menjadi terkesan kumuh, kotor dan menjadi biang keladi kemacetan terutama menjelang malam hari apalagi pada hari libur. Hal tersebut kian diperparah dengan banyaknya kendaraan yang parkir di tepi jalan.

Namun berdasarkan penelitian hasil studi kelayakan di lapangan dapat ditarik kesimpulan bahwa rencana relokasi PKL jl. Sebayu (alun-alun) menuju jl. Pancasila melalui wadah sentra kawasan kuliner Tegal telah dapat diterima (direspons) oleh PKL di kedua kawasan itu dengan baik.

\section{Rekomendasi}

Pihak pemerintah kota Tegal tentunya berharap agar kebijakan relokasi PKL tidak menimbulkan masalah di belakang hari. Untuk itu penelitian ini merekomendasikan:

1. Relokasi PKL jl. Sebayu (alunalun) menuju jl. Pancasila melalui wadah sentra kawasan kuliner Tegal perlu dioptimalisasi dengan kepedulian pemerintah kota Tegal melalui evaluasi kebijakan setiap

periode tertentu

2. Agar kebijakan relokasi diterima (direspons) oleh PKL pada masa-masa mendataang perlu me-libatkan perguruan tinggi dari sisi akademik objektif.

\section{Daftar Pustaka}

Alisjahbana. 2005. Sisi Gelap

Perkembangan Kota. Yogyakarta:

LaksBang PRESSindo.

2005. Marjinalisasi

Informal Perkotaan. Yogyakarta:

LaksBang PRESSindo.

Arikunto, Suharsimi. 1998. Prosedur

Penelitian: Suatu Pendekatan

Praktek. Jakarta: Penerbit

Rineka Cipta.

Arsyad, Lincolyn. 1992. Ekonomi

Pembangunan. Yogyakarta: Bagian Penerbit STIE YKPN.

Boedojo. 1986. Psikologi Manusia dalam

Lingkungan. Jakarta: PT Gramedia

Pustaka Utama.

Catanese, Anthony James dan James C.

Synder. 1997. Perencanaan Kota.

Jakarta: Penerbit Erlangga.

Herlianto. 1986. Urbanisasi dan

Pembangunan Kota. Bandung:

Penerbit Alumni

Nasir, Mohammad, 1988. Metode

Penelitian. Jakarta: Ghalia

Indonesia. 
